成形限界応力を用いた軟鋼板および高強度鋼板の 曲げ曲げ戻し割れ予測

\author{
関口 千春* 箱山 智之** \\ 吹春 寛*** 桑原 利彦****
}

\title{
Fracture Prediction of Mild Steel Sheet and High-Strength Steel Sheet Subjected to Draw-Bending Using Forming Limit Stress Criterion
}

\author{
Chiharu SEKIGUCHI*, Tomoyuki HAKOYAMA**, \\ Hiroshi FUKIHARU ${ }^{* * *}$ and Toshihiko KUWABARA ****
}

(Received on November 30, 2015)

\begin{abstract}
A fracture criterion for sheet metals subjected to draw-bending is investigated using the concept of the forming limit stress criterion. An experimental apparatus that is capable of draw-bending sheet specimens with forming speeds (approximately $100 \mathrm{~mm} \cdot \mathrm{s}^{-1}$ ) comparable to those of real press forming machines is designed and built. The test materials are an ultralow-carbon steel sheet and a 590MPa high-strength steel sheet. Specimens undergo bending-unbending under tension when passing over a die profile. The magnitudes of true stress $\sigma_{\mathrm{DB}}$ at which the stretch-drawn specimens fractured are precisely determined from the measured data of the drawing force and the crosssectional area of the specimen after fracture. Moreover, multiaxial tube expansion tests are performed to measure the forming limit stresses $\sigma_{\mathrm{PT}}$ of the test materials under plane-strain tension. It is found that $\sigma_{\mathrm{DB}}$ is larger than $\sigma_{\mathrm{PT}}$ by $6-18 \%$. Therefore, it is concluded that the forming limit stress criterion is effective for the fracture prediction in draw-bending.
\end{abstract}

Key words: Sheet metal forming, Draw-bending test, Forming limit.

\section{1. 緒 言}

自動車の軽量化による燃費向上と衝突安全性確保を目的 として, 自動車部品への高強度鋼板の適用が拡大している11). しかし高強度鋼板は軟鋼板に比べて延性に劣り成形不良が 多発するため, 金型修正工数の増加が問題となっている. 板材プレス成形時の成形不良の一つに, 金型ダイ肩部に おいて発生する曲げ曲げ戻し変形に起因する破断が挙げら

* 東京農工大学 工学府 機械システム工学専攻

日本学術振興会 特別研究員DC

于184-8588 東京都小金井市中町2-24-16

Graduate School, Department of Mechanical Systems Engineering, Tokyo

University of Agriculture and Technology, 2-24-16, Nakacho, Koganei,

184-8588, Japan.

Research Fellow of Japan Society for the Promotion of Science.

** 日本学術振興会 特別研究員PD (東京農工大学大学院工学研究院) 同上

Institute of Engineering, Tokyo University of Agriculture and Technology, ibid.

****株式会社JSOL CAE技術グループ

干104-0053 東京都中央区晴海2-5-24

Engineering Technology Division, CAE Technology Department,

JSOL Corporation, 2-5-24, Harumi, Chuo-ku, 104-0053, Japan.

****東京農工大学大学院 工学研究院先端機械システム部門

干184-8588 東京都小金井市中町2-24-16

Division of Advanced Mechanical Systems Engineering, Institute of

Engineering, Tokyo University of Agriculture and Technology, 2-24-16,

Nakacho, Koganei, 184-8588, Japan.
れる．材料がダイ肩部を通過する際に曲げられ，壁部で曲 げ戻されることで顕著な板厚減少が起こり2), ダイ肩部通 過直後に破断が誘発される。

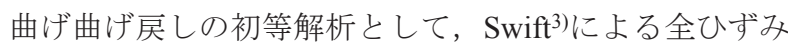
理論を用いた板厚減少量予測および守時4によるひずみ増 分理論を用いたスプリングバック量予測が行われた。 Walp ら 5)は，DP 鋼および CP 鋼について曲げ曲げ戻し試験を行 い, ダイ肩半径 $R$ と板厚 $t$ の比 $(R / t)$ と試験片に加わる公 称応力の関連性を調査した。そして，ダイ肩部において曲 げ曲げ戻し破断が発生する臨界值 $R_{\mathrm{c}} / t$ を実験的に算出した が，この值を直接実部品成形時の破断予測に用いることは 困難である.

$\operatorname{Kim} ら^{6), 77}$ は, DP 鋼, TRIP 鋼の曲げ曲げ戻し試験および 有限要素解析を行った。これら高強度鋼板の場合, 曲げ曲 げ戻し変形時の変形部の温度は $100^{\circ} \mathrm{C}$ 近くまで上昇する. そ のため, 有限要素解析に温度とひずみ, ひずみ速度の影響 を考慮した構成式を用いることで，ひずみが局所化する位 置の予測精度が向上することを示したが，破断基準そのも のは決定していない.

宅田ら ${ }^{8)}$ はバルク材の破壊予測に適用されてきた延性破 壊条件式を用い, アルミニウム合金の深絞り成形解析を行 
った。ダイ肩部およびパンチ肩部で起こる曲げ曲げ戻し変 形後の破断について, 大矢根の式9を導入した有限要素解 析で予測可能であることを示した。 この手法は局部くびれ の発生を伴わない場合の材料の破断予測には効果的である が，軟鋼板のように，局部くびれの発達を伴う場合の破断 予測には不向きである.

板材の破断予測基準として広く用いられる成形限界線 ${ }^{10)}$ は，線形負荷経路で測定された成形限界ひずみを主ひずみ 空間上にプロットしたものである。しかし，成形限界線は ひずみ経路依存性を有する11)ため, 曲げ曲げ戻し変形のよ うに複雑なひずみ経路を辿る変形の破断予測には適さない， 本研究では, 曲げ曲げ戻し変形を受ける部位を対象とし, 実用的な破断判定基準として成形限界応力を適用する手法 を提案する．比例負荷における成形限界応力を主応力空間 上にプロットし，それらを滑らかに繋いで得られる成形限 界応力線は，材料が等方硬化則に従う場合はひずみ経路に 依存しないことが実験的12),13)および解析的14),15)に立証さ れていることから，曲げ曲げ戻し破断を対象とした実用的 な破断判定法として適用できる可能性がある.

齊藤ら ${ }^{16)}$ は，590MPa級二相組織高強度鋼板を用いて，曲 げ曲げ戻し破断時の応力は材料の成形限界応力と一致もし くは上回ることを実験的に立証し, 成形限界応力による曲 げ曲げ戻し破断予測の有効性を示した。しかしこの研究に おける試験片の引抜速度は $1 \mathrm{~mm} \cdot \mathrm{s}^{-1}$ と低速であった。実用 上の適用可能性を確実に検証するためには，実際の製造工 程と同水準の成形速度における曲げ曲げ戻し破断の基礎研 究が必要不可欠である。

そこで本研究では，実成形時と同水準の成形速度（引抜 速度）で曲げ曲げ戻し成形実験が可能な試験機を開発し, 軟鋼板および高強度鋼板について曲げ曲げ戻し試験を行い, 破断時の応力（以下，破断応力）を実測する．併行して， 平面ひずみ引張状態における成形限界応力を二軸バルジ試 験17)により測定し，破断応力の測定值と比較することによ り，曲げ曲げ戻し破断予測における成形限界応力の適用可 能性を検討した結果について報告する.

\section{2. 高速曲げ曲げ戻し試験機の開発}

本研究で開発した高速曲げ曲げ戻し試験機の概観図を Fig. 1に示す. 油圧シリンダBで試験片に後方張力を付与し ながら油圧シリンダAで試験片端部を引き抜くことで，金 型頂点部で試験片に曲げ曲げ戻し変形を加える。曲げ半径 は金型を交換することで任意の值に設定可能である.

試験片引抜側のチャック位置座標は，油圧シリンダ $\mathrm{A} に$ 連結されているリニアポテンショメータで測定し，制御用 パソコンにフィードバックする. 制御用パソコン上で任意 の引抜速度を指定することで，シリンダAによる試験片の 引抜速度を制御することが可能である。油圧シリンダAを 動作させる油圧ユニットにアキュムレータを組み込むこと で， $100 \mathrm{~mm} \cdot \mathrm{s}^{-1}$ オーダーの引抜速度を実現した。油圧シリ ンダBの張力は圧力制御弁で調整し, 試験中は一定圧に保 持する.引抜側荷重および後方張力はともにロードセル(定 格容量 $100 \mathrm{kN}$ ）で測定する.

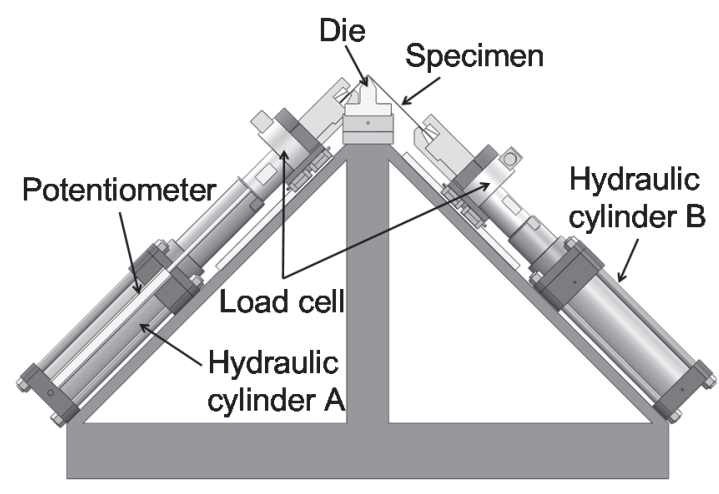

Fig. 1 Schematic of the newly developed draw-bending testing machine

Table 1 Mechanical properties of the test materials (a) JSC270D

\begin{tabular}{c|c|c|c|c|c}
\hline $\begin{array}{c}\text { Tensile } \\
\text { direction } /\end{array}$ & $\begin{array}{c}\sigma_{0.2} \\
/ \mathrm{MPa}\end{array}$ & $\begin{array}{c}c^{*} \\
/ \mathrm{MPa}\end{array}$ & $n^{*}$ & $\alpha^{*}$ & $r^{* *}$ \\
\hline \hline 0 & 156 & 618 & 0.332 & 0.014 & 1.92 \\
\hline 90 & 161 & 623 & 0.349 & 0.018 & 2.13 \\
\hline \multicolumn{6}{c}{ (b) JSC590R } \\
\hline $\begin{array}{c}\text { Tensile } \\
\text { direction } /{ }^{\circ}\end{array}$ & $\begin{array}{c}\sigma_{0.2} \\
/ \mathrm{MPa}\end{array}$ & $\begin{array}{c}c^{*} \\
/ \mathrm{MPa}\end{array}$ & $n^{*}$ & $\alpha^{*}$ & $r^{* *}$ \\
\hline \hline 0 & 464 & 1043 & 0.177 & 0.0089 & 0.718 \\
\hline 90 & 486 & 1037 & 0.169 & 0.0094 & 1.019 \\
\hline
\end{tabular}

*Approximated using $\sigma=c\left(\alpha+\varepsilon^{\mathrm{p}}\right)^{n}$ for $\varepsilon^{\mathrm{p}}=0.002 \sim 0.093$

**Measured at $\varepsilon_{\mathrm{N}}=0.1$

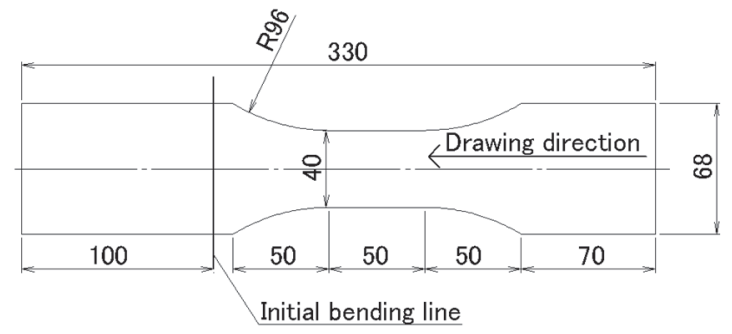

Fig. 2 Specimen used for the draw-bending test (dimensions in $\mathrm{mm})$

\section{3. 実験方法}

\section{1 供試材と試験片}

供試材は，板厚 $t_{0}=1 \mathrm{~mm}$ の極低炭素冷延鋼板JSC270Dお よび590MPa級高強度鋼板JSC590Rである。機械的性質を Table 1に示す．異方性の主軸として，圧延方向（RD）をx 軸，板幅方向（TD）をy軸，板厚方向を $z$ 軸とする。

曲げ曲げ戻し試験に用いた試験片の寸法をFig. 2 に示す. 板幅が板厚の8倍以上のとき, 曲げを受けた板材の板幅方向 中心部は平面ひずみ状態となることから ${ }^{18)}$ ，幅広の試験片 を使用した。圧延方向を長手方向および板幅方向と一致さ せた試験片の2種類を製作した。図中の直線で示す位置 (初 期曲げ位置) で試験片を $90^{\circ} に$ 曲げ，試験機に取り付けた。 試験片が曲げ曲げ戻し変形を受ける区間は成形に伴い断面 積が徐々に減少するので，効率よく曲げ曲げ戻し破断を発 生させることが出来る。なお，上記区間にはあらかじめ 
$2 \mathrm{~mm}$ 格子を転写し, 破断応力決定のための断面積の測定に 供した。

\section{2 曲げ曲げ戻し試験条件}

金型の先端半径（曲げ半径）は $4 \mathrm{~mm}$ とした。ひずみ速度 が破断応力に及ぼす影響を明らかにするために，引抜速度 を5，50および $100 \mathrm{~mm} \cdot \mathrm{s}^{-1}$ の3水準に設定し，各引抜速度に おける試験数は3回とした. 後方張力の值は, 予備実験によ り，全ての引抜速度において試験片が曲げ部通過直後の位 置で破断する最小值として設定し，初期曲げ位置における 公称応力を軟鋼板では $\sigma_{0.2}$ の90\%, 高強度鋼板で $65 \%$ とし た. 試験片と金型が接触する部分には機械油（昭和シェル 石油株式会社製シェルテラスS2 M 32）を塗布した。

\section{3 曲げ曲げ戻し破断後のひずみの算出}

本研究の目的は, 板材の成形限界応力と破断応力を比較 することにより，曲げ曲げ戻し破断予測における成形限界 応力の適用可能性を明らかにすることである. 成形限界応 力は局部くびれ発生時の真応力として定義される. したが って，曲げ曲げ戻し破断時の真応力（破断応力）を成形限 界応力と対比させるためには, 局部くびれと隣接する位置 の断面積を用いて破断応力を算定する必要がある.そこで, 破断後の試験片の板厚分布を試験片長手方向に沿って測定 し，その結果から局部くびれの範囲を同定することで，破 断応力の算定位置を決定した。

まず, RD方向に引き抜いた破断後の試験片をワイヤ放電 加工機で長手方向に切断した. 切断位置は板幅方向中心と, 中心から $\pm 10 \mathrm{~mm}$ および $\pm 15 \mathrm{~mm}$ 離れた位置とした（Fig. 3参 照). 次に測定顕微鏡（ミツトヨ製MF-A1010H）を用いて, 破断部から試験片長手方向に沿って0.1 mm毎に最小読取精 度 $1 \mu \mathrm{m}$ で板厚を測定した。板幅中心および板幅中心から $+10 \mathrm{~mm}$ 離れた箇所の板厚測定結果をFig. 4 亿示す. 軟鋼板, 高強度鋼板ともに，破断部から1.5 2mm離れた位置ならば 局部くびれの外側であると判断できる。また局部くびれの 範囲は引抜速度に依存せず，板幅方向の変動もない。以上 より，破断応力算定のための板厚の測定位置は破断部から $2 \mathrm{~mm}$ の位置と決定した。

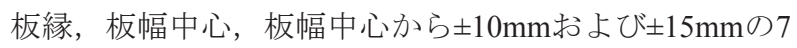
箇所で破断後の板厚を測定顕微鏡で測定し, 板厚方向対数 塑性ひずみ $\varepsilon_{z}^{\mathrm{p}}$ を算出した. 続いて, 板幅方向対数塑性ひず み $\varepsilon_{w}^{\mathrm{p}}$ を決定するために, 破断後の格子間隔を測定顕微鏡で 測定した. 標点距離を $4 \mathrm{~mm}$ と, 板縁, 板幅中心, 板幅中 心から $\pm 10 \mathrm{~mm}$ おび $\pm 15 \mathrm{~mm} の 7$ 箇所で $\varepsilon_{w}^{\mathrm{p}}$ を算出した. 測定 においては破断部に近い格子のうち局部くびれを含まず, 破断や板縁によって欠けていないものを用いた。引抜方向 対数塑性ひずみ $\varepsilon_{l}^{\mathrm{p}}$ は体積一定則 $\left(\varepsilon_{l}^{\mathrm{p}}=-\varepsilon_{w}^{\mathrm{p}}-\varepsilon_{z}^{\mathrm{p}}\right)$ より算出 した.

\section{4 曲げ曲げ戻し破断応力の算出}

曲げ曲げ戻し破断後の試験片断面の模式図をFig. 5に示 す. 板幅中心部 $S_{1}$ は長方形と見なし, 板幅中心の板厚およ び板幅の測定結果を用いて面積を算出した． $S_{2}$ から $S_{5}$ は台 形と見なし， $\pm 10 \mathrm{~mm}$ おび $15 \mathrm{~mm}$ の測定位置における板厚 が台形の上底と下底の和の半分と等しいとして面積を算出 した．S6およびS 7 は板縁の板厚を用いて算出した. 高強度鋼板の破断応力 $\sigma_{\mathrm{DB}}$ の計算式を式(1)に示す.

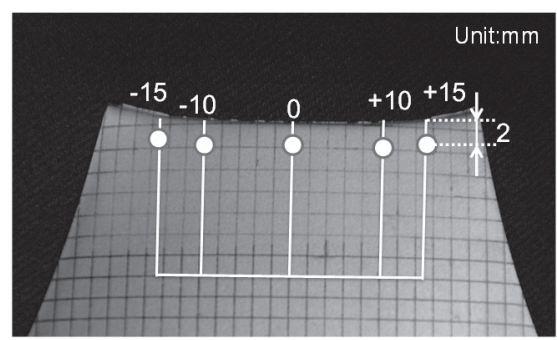

Fig. 3 Positions for thickness strain measurement

(a)

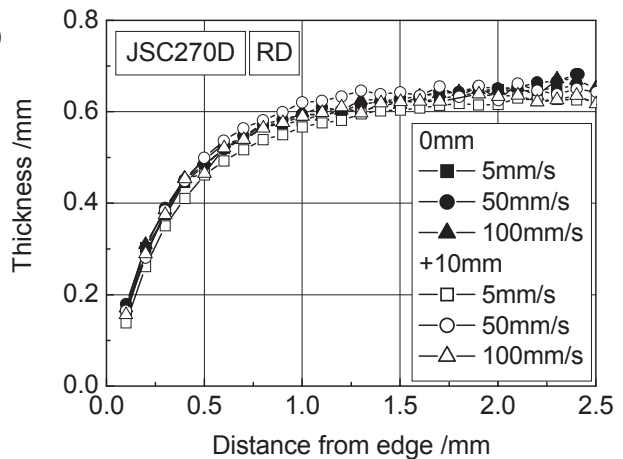

(b)

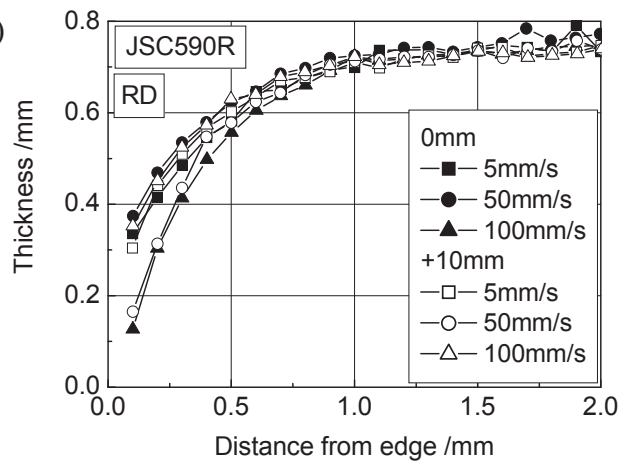

Fig. 4 Thickness distribution along the drawing direction of the fractured specimens in the vicinity of fracture position: (a) JSC270D and (b) JSC590R

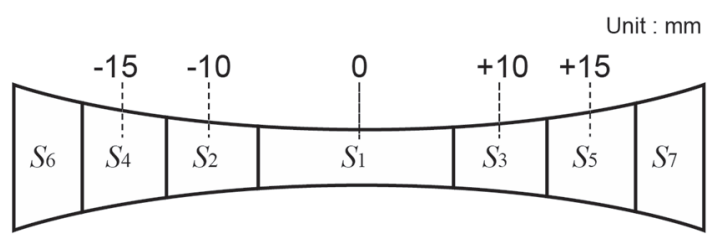

Fig. 5 Division of cross-sectional area

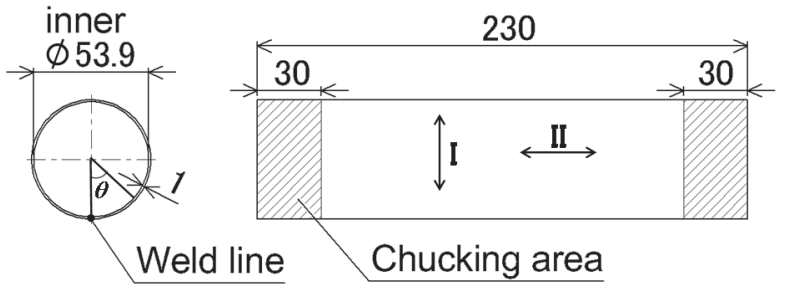

Fig. 6 Specimen used for multiaxial tube expansion test (dimensions in $\mathrm{mm}) \leftrightarrow:$ Rolling direction

$$
\sigma_{\mathrm{DB}}=\frac{F-\sigma_{0,90}\left(S_{6}+S_{7}\right)}{S_{1}+S_{2}+S_{3}+S_{4}+S_{5}}
$$

試験片の板幅方向中央部は平面ひずみ状態で破断し，板縁 
に近づくにつれ単軸状態へと変化する. そのため, 分割し た領域のうち板縁近傍の $S_{6}$ および $S_{7}$ は単軸応力状態で破断 したと見なし，その面積が担った荷重を破断時の荷重Fか ら差し引いた. 単軸引張破断時の応力 $\sigma_{0}$ および $\sigma_{90}$ は, 供 試材の単軸引張試験から得られた真応力一対数塑性ひずみ 曲線をSwiftの式で関数近似した結果と, 曲げ曲げ戻し試験 の結果から算出された $\varepsilon_{l}^{\mathrm{p}}$ の值を対応させて求めた.

軟鋼板は, 平面ひずみ状態で破断した領域が高強度鋼板 に比べて狭いため (4.1節参照), 式(1)に修正を加えた式(2) を用いた。

$$
\sigma_{\mathrm{DB}}=\frac{F-\left[\sigma_{0,90}\left(S_{6}+S_{7}\right)+\sigma_{0,90}^{\prime}\left\{\left(S_{4}+S_{5}\right) / 2\right\}\right]}{S_{1}+S_{2}+S_{3}+\left(S_{4}+S_{5}\right) / 2}
$$

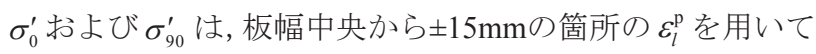
$\sigma_{0}$ と同様に算出した.

\section{5 成形限界応力の測定方法}

供試材の平面ひずみ引張状態における成形限界応力 $\sigma_{\mathrm{PT}}$ を正確に測定するために, Fig. 6に示す円管試験片を用いて

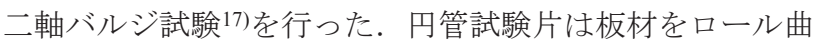
げし， $\mathrm{CO}_{2}$ レーザー溶接して製作した。 そして，サーボ制 御二軸応力試験機17)を用いて円管試験片に軸力と内圧を同 時に負荷した．平面ひずみ引張状態を再現するため，応力 比 $\sigma_{x}: \sigma_{y}=2: 1$ および $1: 2 の$ 線形応力経路かつ, von Misesの 相当塑性ひずみ速度が $5 \times 10^{-4} \mathrm{~s}^{-1}$ となるように制御し

(a)

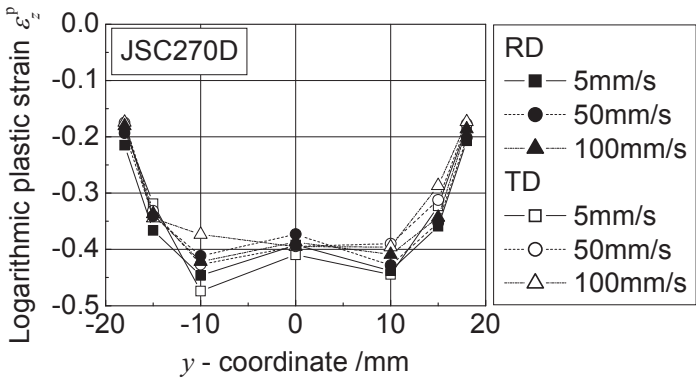

(b)

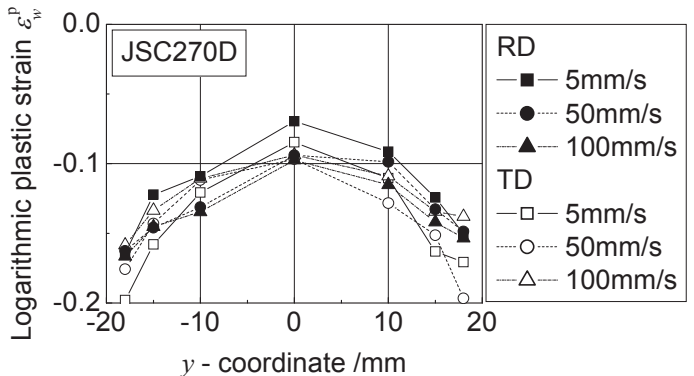

(c)

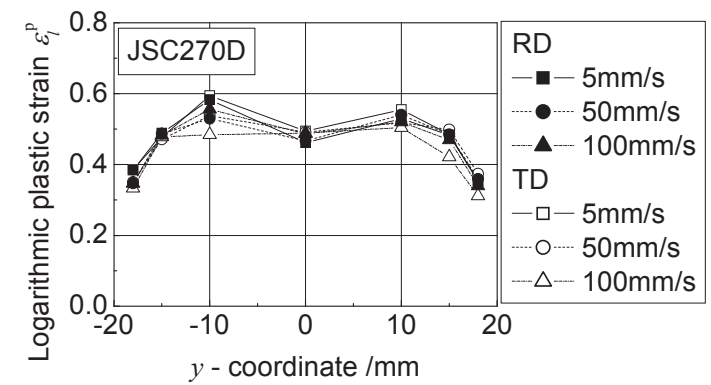

Fig. 7 Strain distribution in the width direction of the JSC 270D specimen: (a) thickness strain $\varepsilon_{z}^{\mathrm{p}}$, (b) width strain $\varepsilon_{w}^{\mathrm{p}}$, and (c) longitudinal tensile strain $\varepsilon_{l}^{\mathrm{p}}$
た. 試験数は各2回とした. 試験片は圧延方向を円周方向と 一致させた試験片Iおよび圧延方向を管軸方向と一致させ た試験片IIの二種類を用意し，最大主応力方向を常に円周 方向に一致させた。試験片の円周方向塑性ひずみが最大值 に達した瞬間 (局部くびれ発生時)の円周方向真応力を $\sigma_{\mathrm{PT}}$ として採用した。

円管試験片は造管時に曲げによる予ひずみが加わるため, 十字形試験片を用いた二軸引張試験によって測定された真 応力一対数塑性ひずみ曲線（以下，SS曲線）を用いて二軸 バルジ試験で測定されたSS曲線の補正を行った。補正方法 の詳細は文献17)を参照されたい.

\section{4. 実験結果と考察}

\section{1 曲げ曲げ戻し試験後のひずみ分布}

破断後の曲げ曲げ戻し試験片における $\varepsilon_{z}^{\mathrm{p}} ， \varepsilon_{w}^{\mathrm{p}} ， \varepsilon_{l}^{\mathrm{p}}$ の板 幅方向分布について，軟鋼板および高強度鋼板の測定結果 をそれぞれFig. 7およびFig. 8に示す．軟鋼板の場合，板幅 中心から $\pm 10 \mathrm{~mm}$ 以内の $\left|\varepsilon_{z}^{\mathrm{p}}\right|$ は $\left|\varepsilon_{w}^{\mathrm{p}}\right|$ の約4倍であり, かつ $\pm 10 \mathrm{~mm}$ よりも外側の值と比較して大きい. よって, 板幅中 心から $\pm 10 \mathrm{~mm}$ 以内では，平面ひずみに近い状態で破断した と判断した。板縁付近では, $\left|\varepsilon_{w}^{\mathrm{p}}\right|$ に対する $\left|\varepsilon_{l}^{\mathrm{p}}\right|$ の比がおよ そ1:2となっている. よって, 板縁付近では単軸引張状態で 破断したと判断した。

高強度鋼板の場合，板幅中心から $\pm 15 \mathrm{~mm}$ 以内の $\left|\varepsilon_{z}^{\mathrm{p}}\right|$ は

(a)

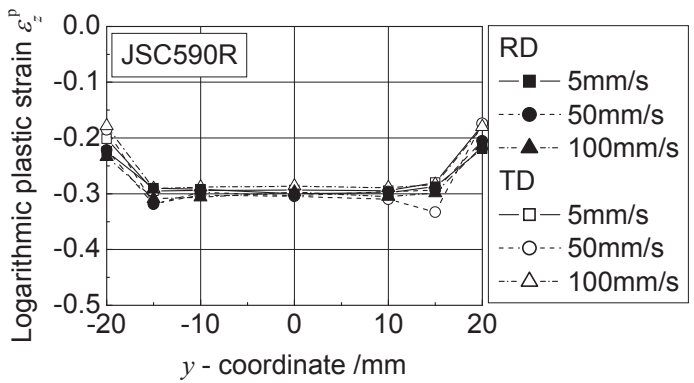

(b)

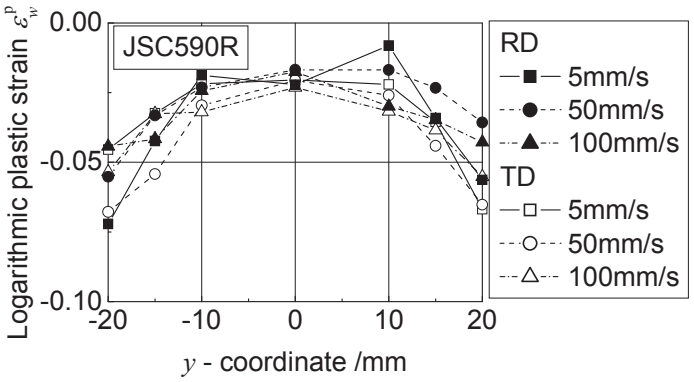

(c)

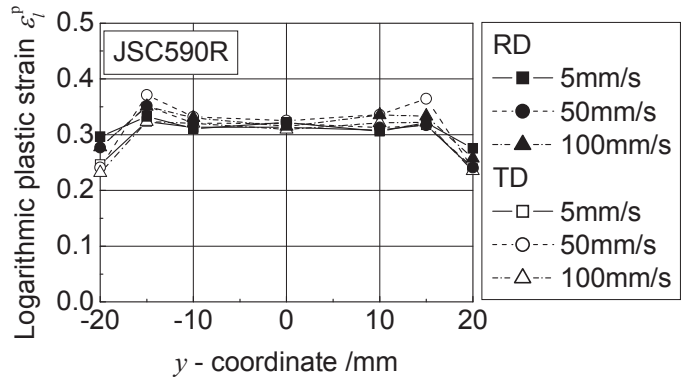

Fig. 8 Strain distribution in the width direction of the JSC 590R specimen: (a) thickness strain $\varepsilon_{z}^{\text {p }}$, (b) width strain $\varepsilon_{w}^{\mathrm{p}}$, and (c) longitudinal tensile strain $\varepsilon_{l}^{\mathrm{p}}$ 
(a)

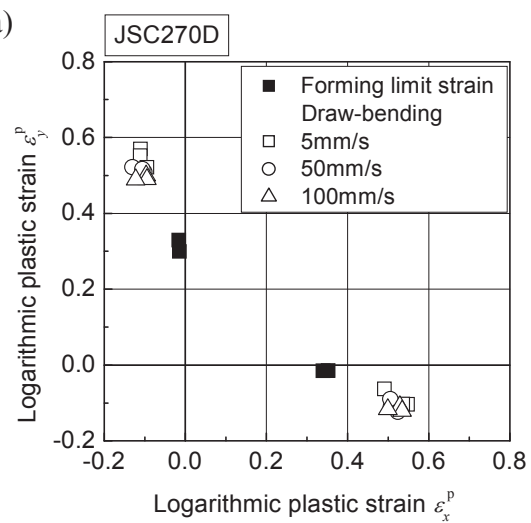

(b)

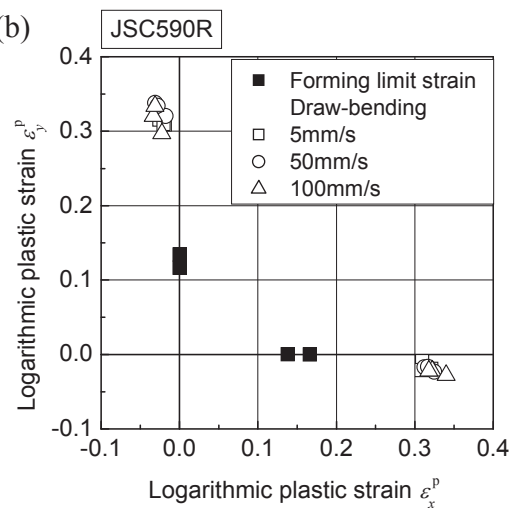

Fig. 9 Forming limit strains: (a) JSC270D and (b) JSC590R

$\left|\varepsilon_{w}^{\mathrm{p}}\right|$ の約10倍である.また, 軟鋼板と同様に, 板縁付近の $\left|\varepsilon_{w}^{\mathrm{p}}\right|$ に対する $\left|\varepsilon_{l}^{\mathrm{p}}\right|$ の比はおよそ1:2となっている. よって, 高強 度鋼板においても, 板幅中心から $15 \mathrm{~mm}$ 以内では平面ひず み状態で破断し, 板縁付近では単軸引張状態で破断したと 判断した.

\section{2 成形限界ひずみとの比較}

曲げ曲げ戻し破断時の $\varepsilon_{l}^{\mathrm{p}}$ および $\varepsilon_{w}^{\mathrm{p}}$, 二軸バルジ試験 から測定された成形限界ひずみとの比較をFig. 9に示す. 成 形限界ひずみと比較して, 軟鋼板の破断時の $\varepsilon_{l}^{\mathrm{p}}$ はおよそ $60 \%$, 高強度鋼板の破断時の $\varepsilon_{l}^{\mathrm{p}}$ はおよそ $100 \%$ 大きくなった。 これより, 成形限界ひずみは破断時のひずみを過少に予測 するため, 破断予測手法として適さないことが示された.

\section{3 成形限界応力との比較}

両供試材における $\sigma_{\mathrm{DB}}$ と $\sigma_{\mathrm{PT}}$ の比較結果をFig. 10に示す. 図中のエラーバーは, 3回の試験結果の標準偏差を示す. 軟 鋼板, 高強度鋼板ともに, 全ての引抜速度において $\sigma_{\mathrm{DB}}$ は $\sigma_{\mathrm{PT}}$ よりも6〜18\%大きくなった． $\sigma_{\mathrm{DB}}$ が $\sigma_{\mathrm{PT}}$ よりも大きく なった理由として, ひずみ速度の増加に伴う塑性流動応力 の増加が考えられる（曲げ曲げ戻し試験におけるひずみ速 度は, 二軸バルジ試験におけるそれのおよそ $10^{3} \sim 10^{4}$ 倍 (付 録 $\mathrm{A}$ 参照)）。そこで, 付録Aの方法に従って, 曲げ曲げ戻し 試験と同水準のひずみ速度における成形限界応力 $\sigma_{\mathrm{PT}}^{\prime}$ を試 算した. その試算值をあわせてFig. 10 に示す. $\sigma_{\mathrm{PT}}^{\prime}$ と $\sigma_{\mathrm{DB}}$ と の差は軟鋼板で $\sigma_{\mathrm{DB}}$ の $4 \sim 8 \%$, 高強度鋼板で $\sigma_{\mathrm{DB}}$ の $0.7 \sim$ $3.9 \%$ となり， $\sigma_{\mathrm{PT}}$ と $\sigma_{\mathrm{DB}}$ の誤差と比較して半分以下となっ た。よってひずタ速度の影響を考慮した成形限界応力を破 断判定基準として用いることにより，曲げ曲げ戻し破断の 予測精度が向上することがわかった。 ただし, 成形条件の ばらつきによる $\sigma_{\mathrm{DB}}$ の変動を考慮すると, $10^{-4} \mathrm{~s}^{-1}$ オーダー

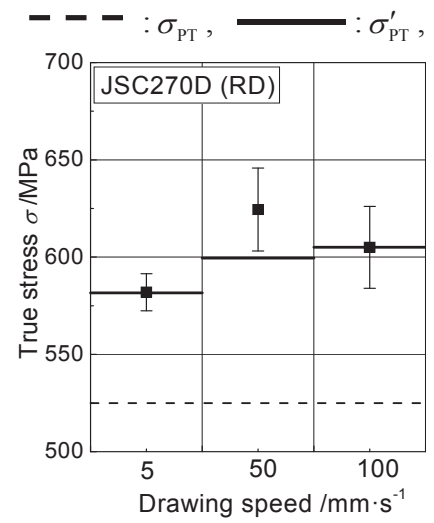

(a)

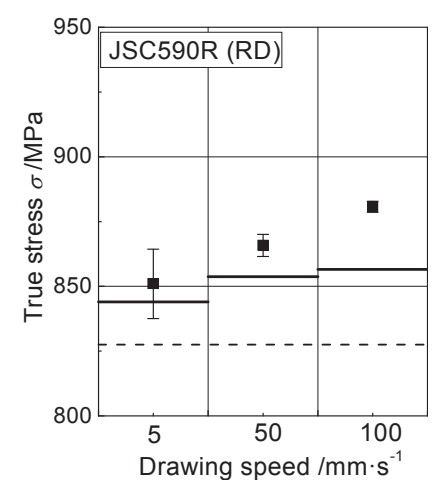

(c)

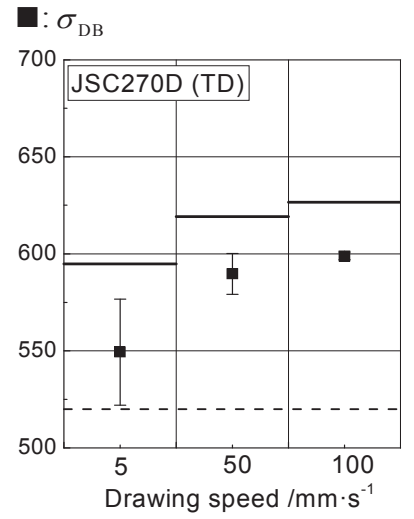

(b)

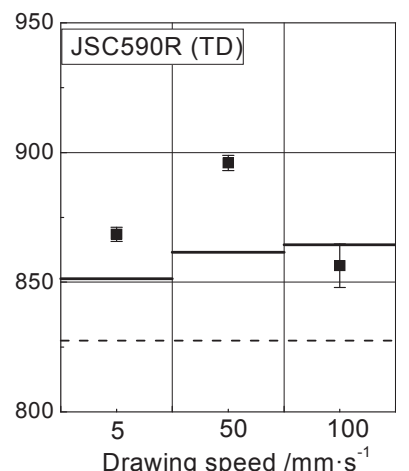

(d)
Fig. 10 Comparisons of forming limit stresses: (a) JSC270D (RD), (b) JSC270D (TD), (c) JSC590R (RD), and (d) JSC590R (TD). $\sigma_{\mathrm{PT}}$ : forming limit stress under plane strain tension measured using the multiaxial tube expansion test, $\sigma_{\mathrm{PT}}^{\prime}$ : forming limit stress under plane strain tension modified by considering the strain rate effect, see Eq. (A.3), $\sigma_{\mathrm{DB}}$ : fracture stress under draw-bending

の準静的ひずみ速度で測定された $\sigma_{\mathrm{PT}}$ に基づいて, $\sigma_{\mathrm{PT}}^{\prime} よ り$ も低めの応力值で安全側に破断判定することも実用上は有 効であると考える.

なお, 曲げ曲げ戻し変形における板内の応力変化を定性 的に理解する一助として, 全ひずみ理論による解析を行っ た。詳細は付録Bを参照されたい.

\section{5. 結 言}

実際の製造工程におけるプレス成形と同水準の引抜速度 で曲げ曲げ戻し成形実験が可能な試験機を開発し, 3水準の 異なるひずみ速度で曲げ曲げ戻し成形試験を行い，成形限 界応力に基づく破断判定法の有効性を検証した. その結果, 以下の知見を得た.

(1) 本研究で用いた軟鋼板および高強度鋼板では， $\sigma_{\mathrm{DB}}$ は $10^{-4} \mathrm{~s}^{-1}$ オーダーのひずみ速度で測定された $\sigma_{\mathrm{PT}}$ よりも6 〜 $18 \%$ 大きくなった．よって， $\sigma_{\mathrm{PT}}$ を破断判定基準とす ることで，曲げ曲げ戻し破断を安全側に予測した。

(2) ひずみ速度の影響を考慮した成形限界応力 $\sigma_{\mathrm{PT}}^{\prime}$ を破断 判定基準として用いることにより, 曲げ曲げ戻し破断の 予測精度が向上する。

(3) 線形負荷経路における成形限界ひずみと比較して, 軟 鋼板の破断時の $\varepsilon_{l}^{\mathrm{p}}$ はおよそ $60 \%$, 高強度鋼板の破断時 
の $\varepsilon_{l}^{\mathrm{p}}$ はおよそ $100 \%$ 大きくなった。これより，成形限界 ひずみは破断時のひずみを過小に予測するため, 破断予 測手法として適さない。

\section{参 考 文 献}

1) 吉武明英 - 池田倫正 : 塑性と加工，52-606 (2011), 766-771.

2) 桑原利彦 - 渡辺和則：塑性と加工, 34-385 (1993), 171-178.

3) Swift, H. W.: Engineering, 166 (1948), 333-359.

4) 守時一: 日本機械学會論文集, 40-330 (1974), 336-353.

5) Walp, M. S., Wurm, A., Siekirk, J. F. \& Desai, A. K.: SAE Tech. pap., (2006), 2006-01-1433.

6) Kim, J. H., Sung, J. H., Piao, K. \& Wagoner, R. H.: Int. J. Plasticity, 27-10 (2011), 1658-1676.

7) Sung, J. H., Kim, J. H. \& Wagoner, R. H.: J. Eng. Mater. Technol., 134-4 (2012), 041015.

8）宅田裕彦・森謙一郎・広瀬智行 -八田夏夫 : 塑性と加 工，36-416 (1995), 985-990.

9) 大矢根守哉: 日本機械学会誌, 75-639 (1972), 596-601.

10) Keeler, S. P. \& Backofen, W. A.: ASM Trans. Q., 56-1 (1963), 25-48.

11) 中島浩衛 : 塑性と加工, 11-109 (1970), 112-118.

12) 吉田健吾・桑原利彦・成原浩二・高橋進: 塑性と加工, 45-517 (2004), 123-128.

13) Yoshida, K. \& Kuwabara, T.: Int. J. Plasticity, 23-7 (2007), 1260-1284.

14) Yoshida, K, Kuwabara, T. \& Kuroda, M.: Int. J. Plasticity, 23-3 (2007), 361-384.

15) Yoshida, K. \& Suzuki, N.: Int. J. Plasticity, 24-1 (2008), 118-139.

16) 齊藤正純 - 桑原利彦 : 平成 25 年度塑性加工春季講演 会講演論文集，(2013)，159-160.

17) Kuwabara, T. \& Sugawara, F.: Int. J. Plasticity, 45 (2013), 103-118.

18）日本塑性加工学会: 曲げ加工, (1995), 4-7, コロナ社.

19) Kuroda, M., Uenishi, A., Yoshida, H. \& Igarashi, A.: Int. J. Solids Struct., 43 (2006), 4465-4483.

\section{付録 A：ひずみ速度の増加に伴う成形限界応力の 増加量の算定方法}

試験片の初期板厚を $t_{0}$, 金型先端丸味半径を $R$, 試験片 の引抜速度を $V$ とすると, 試験片が金型先端丸味半径部を 通過する時間 $\tau$ は次式で近似できる.

$$
\tau=\frac{\pi\left(R+t_{0} / 2\right)}{2 V}
$$

曲げ曲げ戻し変形によるひずみ増分は試験片に加わった 相当塑性ひずみ $\bar{\varepsilon}$ と等しいと見なすと, 曲げ曲げ戻し変形 を受ける試験片のひずみ速度 $\dot{\varepsilon}_{\mathrm{BU}}$ は次式で概算できる. (a)

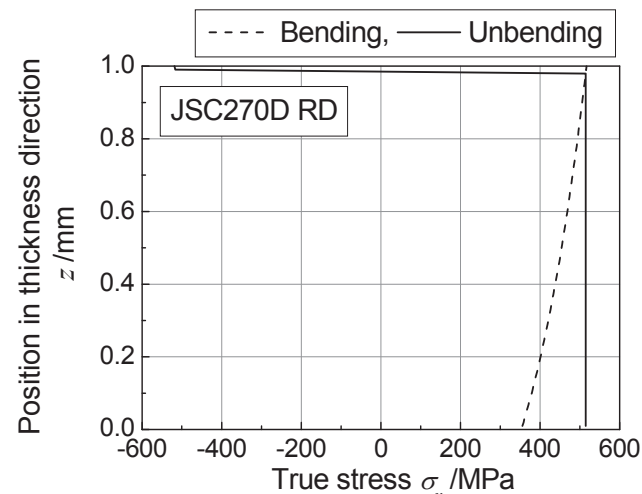

(b)

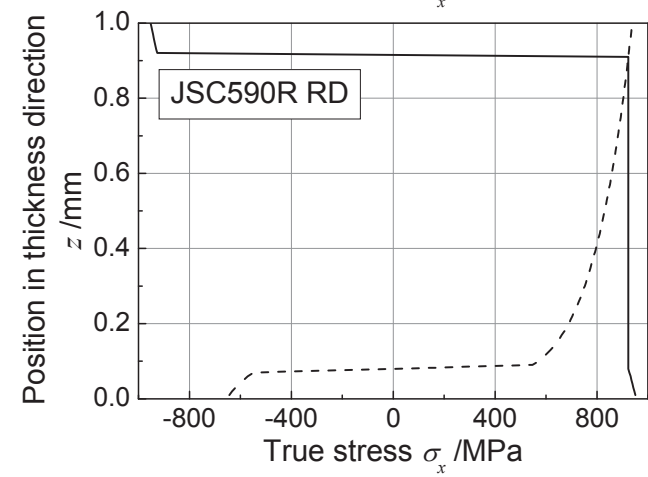

Fig. B.1 Calculated results of the stress distribution in the thickness direction after bending and unbending. (a) JSC 270D and (b) JSC 590R

$$
\dot{\varepsilon}_{\mathrm{BU}}=\frac{\bar{\varepsilon}}{\tau}=\frac{2 \bar{\varepsilon} V}{\pi\left(R+t_{0} / 2\right)}
$$

ここで̄にしいては, von Misesの相当塑性ひずみを仮定し， 4.1節に示す各塑性ひずみの測定結果から算出した結果の 平均值を用いた。その結果，軟鋼板の場合 $\bar{\varepsilon}=0.53$ ，高強 度鋼板の場合 $\bar{\varepsilon}=0.35$ を得た。加えて本研究における試験 条件， $V=5,50$ および $100 \mathrm{~mm} \cdot \mathrm{s}^{-1}, R=4 \mathrm{~mm}, t_{0}=1 \mathrm{~mm}$ 式(A.2)に代入すると, 各 $V$ に対して, 軟鋼板の場合 $\dot{\varepsilon}_{\mathrm{BU}}=$ $0.4,3.7$ おび $7.5 \mathrm{~s}^{-1}$, 高強度鋼板の場合 $\dot{\varepsilon}_{\mathrm{BU}}=0.2,2.5$ およ び $4.9 \mathrm{~s}^{-1}$ を得た。

次に，成形限界応力に及ぼすひずみ速度の影響を概算す るために式(A.3)を用いた。

$$
\bar{\sigma}_{\mathrm{PT}}^{\prime}=\bar{\sigma}_{\mathrm{PT}}+D \ln \left(\frac{\dot{\Phi}}{\dot{\varepsilon}_{\mathrm{R}}}\right)
$$

式(A.3)は, Kurodaら 19) の提案による構成式において温度に 係る項を無視した簡略式である。ここで， $\bar{\sigma}_{\mathrm{PT}}$ は，平面ひ ずみ引張状態における成形限界応力の測定值 $\sigma_{\mathrm{PT}}$ から von Mises の降伏条件式を仮定して得られる相当応力 $\bar{\sigma}_{\mathrm{PT}}$ $\left(=\sqrt{3} \sigma_{\mathrm{PT}} / 2\right), \quad \dot{\Phi}$ はひず夕速度， $\dot{\varepsilon}_{\mathrm{R}}\left(=5 \times 10^{-4} \mathrm{~s}^{-1}\right)$ は基準 となる $\sigma_{\mathrm{PT}}$ を実測した際のひずみ速度である.パラメータ $D$ は， $\dot{\Phi}=0.1 \mathrm{~s}^{-1}$ および $5 \times 10^{-4} \mathrm{~s}^{-1}$ における単軸引張応力の測定 值より決定した. その結果, 軟鋼板では $D=6.8 \mathrm{MPa}(\mathrm{RD})$, $9.2 \mathrm{MPa}(\mathrm{TD})$, 高強度鋼板では $D=3.6 \mathrm{MPa}(\mathrm{RD}), 3.8 \mathrm{MPa}$ （TD） と算定した.

式(A.3)の $\dot{\Phi} に \dot{\varepsilon}_{\mathrm{BU}}$ を代入し, そのひずみ速度に対応する 相当応力 $\bar{\sigma}_{\mathrm{PT}}^{\prime}$ を算出し, その值から平面ひずみ引張状態に 
おける成形限界応力 $\sigma_{\mathrm{PT}}^{\prime} \quad\left(=2 \bar{\sigma}_{\mathrm{PT}}^{\prime} / \sqrt{3}\right)$ を求めた.

\section{付録 B : 曲げ曲げ戻し変形時の板厚方向応力分布}

曲げ曲げ戻し変形時の応力分布を評価するため, 全ひず み理論による初等解析を行った. von Misesの降伏条件式お よび板幅不変の平面ひずみ変形を仮定し，バウシンガ効果 と材料発熱は無視した。解析方法の詳細は文献2)を参照さ れたい. 曲げおよび曲げ戻し変形時における張力は, 本研 究における試験片破断時の引抜力 $F$ の測定值に等しいと仮 定した. 板厚方向分割数は 100 とし, 断面積の算出に用いる 板幅の值には測定值を用いた。

曲げおよび曲げ戻し後の応力の計算值をFig. B. 1 亿示す.
軟鋼板では，外表面のひずみ増分は曲げ時で 0.31 , 曲げ戻 し時で-0.004である。曲げ時は面内に中立面が存在せず, 曲げ戻し時にひずみが反転する範囲は最外面の要素のみで ある. 高強度鋼板では, 外表面のひずみ増分は曲げ時で 0.20 , 曲げ戻し時で-0.018である。曲げおよび曲げ戻し時にひず みが反転する範囲は板厚のおよそ $10 \%$ である以上より， 破断応力に及ぼすバウシンガ効果の影響は小さいと推測さ れ，その結果，成形限界応力と破断応力が概ね一致する結 果となったと考える。

なお, 実験と計算における $\varepsilon_{l}^{\mathrm{p}}$ の差異は, 計算上の仮定 (平 面ひずみ状態，材料発熱なし，von Misesの降伏条件式）が 実験では成立しないことに起因寸ると考える。 